Вип. 11. - С. 95-98. 5. Малихін О. В. Теоретико-методологічні засади організації самостійної навчальної діяльності студентів вищих навчальних закладів : дис. ... д-ра пед. наук: спец. 13.00.09 / О. В. Малихін; Криворіз. держ. пед. ун-т. - Кривий Ріг, 2009. - 504 с. 6. Солдатенко М. М. Теорія і практика самостійної пізнавальної діяльності: [монографія] / М. М. Солдатенко. - К. : Вид-во НПУ ім. М. П. Драгоманова, 2006. - 198 с.

УДК $371.134: 80$

Олександра Лисевич

\title{
ФОРМУВАННЯ ТВОРЧОЇ ОСОБИСТОСТІ МАЙБУТНЬОГО ВЧИТЕЛЯ ПОЧАТКОВИХ КЛАСІВ
}

Лисевич О. В. Формування творчої особистості майбутнього вчителя початкових класів.

У статті розглядається проблема формування творчої особистості майбутнього вчителя початкових класів, підходи та шляхи іiі формування. На думку автора, є необхідність у забезпеченні умов, які сприяли б виявам творчої активності, створення творчого мікроклімату, проблемно-пошукової атмосфери, необхідної для формування позитивних мотивів креативної діяльності. Автор стверджує, що необхідними умовами для вияву творчості в педагогічній діяльності $є$ наявність творчих особистостей, творчого процесу, творчого середовища.

Ключові слова: креативність, творча особистість, творчий потенціал, творчий процес, творче середовище, професіоналізм майбутніх учителів початкових класів.

Лисевич А. В. Формирование творческой личности будущего учителя начальных классов.

В статье рассматривается проблема формирования творческой личности будущего учителя начальных классов. С точки зрения автора, необходимо обеспечить условия, которые способствовали б проявлениям творческой активности, создать творческую атмосферу, необходимую для формирования позитивной мотивации, креативной деятельности. Автор утверждает, що необходимыми условиями для проявления творчества в педагогической деятельности является наличие творческих личностей, творческого процесса, творческой среды.

Ключевые слова: креативность, творческая личность, творческий потенциал, творческий процесс, творческая среда, профессионализм будущих учителей начальных классов.

Lysevich A. V. The creativity as a feature of the professionalism of the future elementary school teacher.

The article reveals the problem of the formation of the creative personality of the future elementary school teacher, and the approaches and means of its formation. The author states that it is necessary to create the circumstances which would stimulate the creative activity, and the creative atmosphere which is of great need for the formation of positive motivation and creative activity. The author also insists that the presence of creative personalities, creative process, and creative environment are the important factors for the realization of the pedagogical creativity in the process of teaching.

Key words: creativity, creative personality, creative potential, creative process, creative environment, the professionalism of the future elementary school teacher.

У сучасній науці спостерігається активізація досліджень щодо розв'язання проблеми творчості, оскільки визнано, що творчі досягнення мають соціальну цінність. Основне завдання науки полягає в розкритті закономірностей і механізмів творчого процесу, креативності (англ. creativity - творчість).

Творчість як основа та механізм розвитку психіки досліджувалась у роботах Н. Кіпіані, О. Матюшкіна, Я. Пономарьова, І. Семенова та ін.; творчість та закономірності мислення розглядались Н. Алексєєвим, С. Бернштейном, В. Біблером, О. Тихомировим, Е. Юдіним. Дослідженням креативності здіснювали Дж. Гілфорд, В. Сміт, К. Тейлор, Е. Торренс, Х. Трік, Д. Халперн та ін.

Більшість дослідників у визначенні креативності роблять акцент на особливостях або специфічних рисах особистості. На думку Дж. Гілфорда, креативність і творчий потенціал можуть бути визначеними як сукупність здібностей, особистісних рис, які сприятимуть успішному творчому мисленню [1]. 
Дж. Гілфорд називав мислення творчим у тому разі, якщо в ньому домінують чотири ознаки: оригінальність, семантична гнучкість, образна адаптивність та семантична спонтанна гнучкість.

Перша ознака творчої особистості полягає у нетривіальності, незвичайності висловлюваних думок, у яскраво вираженому прагненні до інтелектуальної оригінальності. Творча людина майже завжди прагне знайти і виявити власне, відмінне від інших рішення.

Друга ознака - семантична гнучкість, яка полягає у здатності бачити старий об'єкт під новим кутом зору: те, чого раніше не помічали, що приховане від стороннього спостерігача, але внутрішньо йому притаманне; виявляти нові способи використання об'єкта, функціональне застосування на практиці.

На відміну від семантичної образна адаптивна гнучкість, що є третьою ознакою творчої особистості, полягає у здатності видозмінювати сприйняття об'єкта в такий спосіб, щоб бачити його нові, приховані від спостерігача сторони.

Четверта ознака, семантична спонтанна гнучкість, означає здатність продукувати різноманітні ідеї у невизначеній ситуації, зокрема у такій, що не містить орієнтирів для цих ідей, не дає прямих «підказок».

У багатьох дослідженнях креативності стверджується, що творчий потенціал притаманний кожній особистості, але в різній кількості та якості, проблема полягає тільки в з'ясуванні механізмів його розкриття.

Особливості творчості у навчанні та вихованні, механізми творчої діяльності розглядалися у працях В. Давидова, І. Зимньої, Н. Кузьміної, О. Матюшкіна, Я. Пономарьова.

У контексті педагогічної діяльності проблема творчості розглядалася М. Поташником, який наголошує на ії практичному застосуванні: нестандартний підхід до розв'язання проблем; розроблення нових методів, засобів, прийомів і форм в оригінальному поєднанні; ефективне застосування досвіду; удосконалення, раціоналізація, модернізація відомого відповідно до нових задач; імпровізація на основі як інтуїції, так і перевірених знань; уміння бачити всі варіанти проблеми; уміння трансформувати методичні рекомендації, теоретичні положення в конкретні педагогічні дії.

М. Поташник розрізняе «педагогічну майстерність» і «педагогічну творчість», наголошуючи на тому, що майстерність пов'язана з досвідом, а творчість - ні [3].

Метою статті є спроба виокремити основні підходи та шляхи формування творчої особистості майбутніх учителів початкових класів.

Проблема формування творчої особистості майбутнього вчителя початкових класів розглядалася в контексті розвитку творчої уяви та фантазії; механізмів творчої діяльності; впливів соціального середовища на розвиток творчої особистості; можливостей управління творчою діяльністю; виховання творчої особистості в колективі.

На сучасному етапі розгляд творчої особистості відбувається в контексті фахової компетентності як передумови її майбутнього професіоналізму (Л. Хомич) [6].

Якщо проаналізувати педагогічний процес у контексті формування творчої особистості майбутнього вчителя початкових класів, то можна виокремити у ньому два напрямки: перший пов'язаний із процесом підготовки педагога до творчості, а другий - творчістю під час безпосередньої взаємодії зі студентами. Спілкування як компонент педагогічної творчості, творчість у спілкуванні викладача і студента $\epsilon$ необхідною умовою продуктивної педагогічної діяльності.

Багато дослідників звертає увагу на те, що у викладанні педагог спирається на здатність студентів до запам'ятовування, а не на евристичне мислення, імпровізацію тощо. На думку багатьох науковців, є необхідність у створенні умов, які сприяють виявленню творчої активності, створенню творчого мікроклімату, проблемно-пошукової атмосфери, необхідної для формування позитивних мотивів креативної діяльності [2].

У концепції педагогічної освіти, запропонованої В. Сластьоніним, як головний напрямок, що сприяє становленню суб'єктивної позиції педагога, виокремлюється розв'язання педагогічних задач, які зумовлюють формування основних компонентів педагогічного мислення: аналіз, рефлексія, планування [5].

Практичні задачі виникають у конкретних ситуаціях навчальної діяльності та вимагають від викладача враховувати всі умови, які утворюють педагогічну ситуацію. За словами Н. Кузьміної, творчість педагога виявляється у тому, що він проектує особистість майбутнього 
вчителя, імпровізує у нестандартних ситуаціях, будує навчальний процес, ураховуючи індивідуальні риси особистості студента [3].

Отже, можна стверджувати, що необхідними умовами для вияву творчості у педагогічній діяльності є наявність творчих особистостей, творчого процесу, творчого середовища.

Багато дослідників намагалися створити теорію творчості, але підходи та витлумачення їх істотно відрізнялись. Найпоширеніше визначення творчості зазвичай зводиться до такої формули: творчість - це діяльність, у результаті якої створюються матеріальні й духовні цінності, які мають новизну і суспільну значущість. Ця тенденція характеризувати творчість через новизну і соціальну значущість властива багатьом дослідникам.

Водночас специфікою педагогічної діяльності є розуміння творчості як особливого виду особистісної активності продуктивного характеру. Результати досліджень свідчать про значний вплив біологічних та соціальних умов щодо формування та вияву креативності.

Здатність до творчості в особистості майбутнього вчителя перебуває в тісному взаємозв'язку зі специфікою іiї пізнавальних процесів та особистісних рис. Вияв креативності виражається не стільки у знаннях (правилах, законах), скільки у сприйнятливості до нових проблем, ідей; схильності до руйнування стереотипів задля створення нового.

Ефективність формування творчої особистості майбутніх учителів початкових класів зумовлена виявленням умов й усуненням суперечностей між вимогами, що висуваються до особистості та діяльності майбутнього вчителя початкових класів і наявним рівнем творчої компетентності. Стан досліджуваної проблеми формування творчої компетентності майбутніх учителів початкових класів вимагає подальших наукових пошуків: методика діагностування рівнів сформованості творчої компетентності майбутнього вчителя початкових класів, показники і критерії іiї сформованості, розроблення моделі та технології іiї формування.

\section{Література}

1. Бурлачук Л. Ф. Словарь-справочник по психодиагностике / Л. Ф. Бурлачук, С. М. Морозов. [2-е изд.]. - СПб. : Питер, 2004. - 520 с. 2. Морозов А. В. Креативная педагогика и психология: [учеб. пособ.] / А. В. Морозов, Д. В. Чернилевский. - [2-е изд.]. - М. : Академический Проект, 2004. - 560 с. 3. Кузьмина Н. В. Профессионализация личности преподавателя и мастера производственного обучения / Нина Васильевна Кузьмина. - М. : ВШ, 1990. - 118 с. 4. Поташник М. М. Требования к современному уроку: [учеб. пособ.] / Марк Максимович Поташник. - М. : Центр педагогического образования, 2011. - 272 с. 5. Сластенин В. А. Введение в педагогическую аксиологию: [учеб. пособ. для студ.] / В. А. Сластенин, Г. И. Чижакова. - М. : Изд. центр «Академия», 2003. - 192 с. 6. Хомич Л. О. Професійно-педагогічна підготовка вчителя початкових класів / Лідія Олексіївна Хомич. - К. : Магістр-S, 1998. - 201 c.

УДК 378.147: 377. 112.4

Ірина Максименко

\section{ФОРМУВАННЯ ПЕДАГОГІЧНОЇ ТЕХНІКИ В МАЙБУТНІХ ПЕДАГОГІВ ПРОФЕСІЙНОГО НАВЧАННЯ У ПРОЦЕСІ ФАХОВОЇ ПІДГОТОВКИ}

Максименко І. Г. Формування педагогічної техніки в майбутніх педагогів професійного навчання у процесі фахової підготовки.

У статті розкривається сутність і зміст педагогічної техніки та технологія ії̈ формування в майбутніх педагогів професійного навчання, схарактеризовано етапи формування педагогічної техніки під час вивчення дисципліни «Комунікативні процеси в педагогічній діяльності».

Ключові слова: педагогічна техніка, зовнішня техніка, техніка мовлення, внутрішня техніка.

Максименко И. Г. Формирование педагогической техники у будущих учителей профессионального обучения в процессе специальной подготовки.

В статье раскрывается сущность и содержание педагогической техники и технология ее формирования у будущих педагогов профессионального обучения, охарактеризованы этапы формирования педагогической техники при изучении дисциплины «Коммуникативные процессы в педагогической деятельности».

Ключевые слова: педагогическая техника, внешняя техника, техника речи, внутренняя техника. 